\title{
Landfill leachates and wastewater of maritime origin as possible sources of endocrine disruptors in municipal wastewater
}

\author{
Barbara K. Wilk ${ }^{1}$ - Sylwia Fudala-Ksiazek ${ }^{2}$ - Małgorzata Szopińska ${ }^{1} \cdot$ Aneta Luczkiewicz $^{1}$ (D) \\ Received: 16 February 2019 / Accepted: 23 May 2019 / Published online: 2 July 2019 \\ (C) The Author(s) 2019
}

\begin{abstract}
In this study, wastewater from municipal services, such as a port wastewater reception facility (PRF-WW) and a municipal solid waste plant (MSWP), was tested for the presence of the suspected endocrine-disrupting compounds phthalates (PAEs) and bisphenol A (BPA). PAEs and BPA were found in this study in high concentrations in raw wastewater obtained from passenger ships (RMT-WWs) (up to $738 \mu \mathrm{g} / \mathrm{L}$ and $957 \mu \mathrm{g} / \mathrm{L}$, respectively) collected in the Port of Gdynia and in landfill leachates (LLs) (up to $536 \mu \mathrm{g} / \mathrm{L}$ and up to $2202 \mu \mathrm{g} / \mathrm{L}$, respectively) from a MSWP located near Gdynia. In particular, the presence of reprotoxic di(2-ethylhexyl) phthalate (DEHP, up to $536 \mu \mathrm{g} / \mathrm{L}$ in LLs and up to $738 \mu \mathrm{g} / \mathrm{L}$ in RMT-WWs) requires further action because if this compound, as well as other PAEs and BPA, is not degraded by activated sludge microorganisms, it may reach receiving waters and adversely impact aquatic organisms. Therefore, PAEs and BPA should be removed either during the onsite pretreatment of tested industrial wastewater or during tertiary treatment at municipal wastewater treatment plants (WWTPs, representing end-of-pipe technology).
\end{abstract}

Keywords Micropollutants · Landfill leachates · Cruise ship wastewater · Municipal and industrial wastewater · Treatment approach

Highlights (the main findings of the work)

- Industrial wastewater was tested for the presence of endocrine-disrupting compounds.

- Wastewater from municipal solid waste plants and port reception facilities was highly polluted by PAEs and BPA.

- The reprotoxin DEHP reached $536 \mu \mathrm{g} / \mathrm{L}$ in landfill leachates and $738 \mu \mathrm{g} / \mathrm{L}$ in raw wastewater of maritime origin.

- Micropollutants after discharge to a municipal WWTP may pass untreated similar to other inert compounds.

Responsible editor: Ester Heath

Electronic supplementary material The online version of this article (https://doi.org/10.1007/s11356-019-05566-4) contains supplementary material, which is available to authorized users.

Barbara K. Wilk

barbara.k.wilk@pg.edu.pl

Aneta Luczkiewicz

ansob@pg.gda.pl

Sylwia Fudala-Ksiazek

sksiazek@pg.edu.pl

Małgorzata Szopińska

malgorzata.szopinska@pg.edu.pl
1 Department of Water and Wastewater Technology, Faculty of Civil and Environmental Engineering, Gdansk University of Technology, 11/12 Narutowicza St., 80-233 Gdansk, Poland

2 Department of Sanitary Engineering, Faculty of Civil and Environmental Engineering, Gdansk University of Technology, 11/12 Narutowicza St., 80-233 Gdansk, Poland 


\section{Introduction}

Proper wastewater management plays a crucial role in achieving good water status and the potential restoration of water resources. To mitigate the environmental burden of wastewater, the following two approaches are generally considered: cleaner production and end-of-pipe technology (Chour 2001). Cleaner production is thought to reduce resource usage and/or pollution emissions, but past and even current environmental regulations rely far more on the end-of-pipe approach. The quality standards for wastewater discharge, however, can underestimate the impact of a particular substance on the ecosystem due to the limited knowledge of concertation-response effects (Connon et al. 2012).

Micropollutants can enter the aquatic environment through both diffuse and point sources; however, in urbanized regions, wastewater treatment plants (WWTPs) play a crucial role in their dissemination. Conventional WWTPs are effective in macropollutant removal, while micropollutants may pass through the treatment process unchanged or are removed at different rates. Most EU countries are convinced that the presence of micropollutants in the environment poses a serious problem, particularly in highly populated regions, where water resources are used for drinking and irrigation purposes and as wastewater receivers. It has already been confirmed that insufficient removal of micropollutants by WWTPs and by water treatment plants can result in the presence of endocrinedisrupting compounds (EDCs) in drinking water (Albergamo et al. 2019; Badach et al. 2007; Tröger et al. 2018). Of special concern are water bodies that receive a high fraction of treated wastewater discharged from several WWTPs simultaneously because the combined and cumulative impact of micropollutants can occur under such conditions (Logar et al. 2014). In many countries, reduced dilution potential of surface water bodies occurs during summer droughts, increasingly reported in recent years (Englert et al. 2013).

Thus, there is growing concern about persistent and bioactive micropollutants (Dévier et al. 2011), which may enter the water body via different pathways. In the case of municipal WWTPs, some micropollutants that are resistant to biodegradation are usually not completely removed via conventional WWTP techniques (Luo et al. 2014). Of special concern are priority substances specified by the Directive 2013/39/EU. The current challenge in water policy is, however, not only the monitoring of micropollutants in water bodies but also the identification of their sources and implementation of possible technologies to mitigate their release. Industrial facilities discharge wastewater into the environment either (a) directly through their own sewerage and onsite wastewater treatment system or (b) indirectly via municipal WWTPs. Currently, more industrial plants have decided to pretreat wastewater on site to guarantee the quality required by the relevant legislation (for details, see Table S1 in Supplementary materials). Unfortunately, the effectiveness of micropollutant removal is rarely checked; thus, it is suspected that some emerging compounds (e.g., with limited biodegradation) are still directed to municipal WWTPs (Chour 2001).

Thus, it is necessary to better understand the demands and related costs of complying with the EU standards for water quality (for more, see Table S1). In this study, there was a special focus on wastewater onsite pretreatment of industrial wastewater originating from municipal services, such as landfill leachates (LLs) generated at municipal solid waste plants (MSWPs) and maritime wastewater (MTWW) from port reception facilities (PRFs-WW). LLs are defined as liquids that pass through deposited solid waste, leaching dissolved and suspended matter, and due to the complex composition of LLs (Fudala-Ksiazek et al. 2016, 2017; Kulikowska and Klimiuk 2008; Renou et al. 2008; Wiszniowski et al. 2006), several processes have been tested to solve the challenging LL treatment issues (Boonnorat et al. 2016; Fudala-Ksiazek et al. 2018; Liu et al. 2017; Mandal et al. 2017; Wojciechowska 2017). The effectiveness of these methods, however, has rarely been analysed in terms of micropollutant removal (Fudala-Ksiazek et al. 2017, 2018; Yi et al. 2017).

The generation of MT-WWs is also of special concern because the number of people transported by cruise liners and ferries on the Baltic Sea has increased by an average of $9.9 \%$ annually (from 1.1 million in 2000 to 4.3 million in 2016) (Cruise Baltic 2016, 2017; Kovalevskiene et al. 2017). Furthermore, since January 2013, the Baltic Sea has become the first special area with mandatory limits for the discharge of phosphorus ( $\max 1.0 \mathrm{mg} / \mathrm{L}$ or $80 \%$ reduction) and nitrogen ( $\max 20 \mathrm{mg} / \mathrm{L}$ or $70 \%$ reduction) (for details, see Table S1 in Supplementary Materials). These limits make it necessary to equip ships with appropriate treatment systems or to equip ports with wastewater reception facilities (PRFs-WW) (Table S2) (HELCOM 2018). Unfortunately, the presence and dissemination of micropollutants via MT-WWs have been overlooked (Nödler et al. 2014; Carić 2016). If discharged to a PRF-WW, MT-WWs are usually then directed to local WWTPs (Carić 2016; Directive 2455/2001/EC; Prior 2013). However, as in the case of LLs, there is a lack of data regarding the presence of micropollutants in MT-WWs and their fate in municipal wastewater treatment.

The aim of this study is to determine the presence of BPA and selected PAEs (DMP — dimethyl phthalate, DEP — diethyl phthalate, DnBP — di-n-butyl phthalate, BBzP - benzyl butyl phthalate, DEHP - bis(2-ethylhexyl) phthalate, and DnOPdi-n-octyl phthalate) in wastewater generated by MSWP (LLs) and originated from PRF-WW (MT-WW). The selection of BPA and PAEs was related to their common presence in numerous products and tendency to end up in solid waste streams and/or maritime wastewater. Both PAEs and BPA can be ingested by a wide range of marine organisms and then negatively affect their endocrine system, resulting in impaired reproduction, loss of biodiversity, incidence of hormonesensitive cancers, and other effects (Hermabessiere et al. 
2017). According to HELCOM (Baltic Marine Environment Protection Commission, 2010), the concentrations of these compounds in biota from coastal regions are generally high (PAEs: $50 \mu \mathrm{g} \mathrm{kg}^{-1}$ wet weight in fishes and $2500 \mu \mathrm{g} \mathrm{kg}^{-1}$ dry weight in sediment; BPA: $45 \mu \mathrm{g} \mathrm{kg}^{-1}$ wet weight in fishes). In this study, BPA and selected PAEs were also determined in municipal wastewater entering the WWTPs (IN-WWTP). These results are regarded as a baseline condition due to the planned connection of local WWTPs to the abovementioned PRF-WW and MSWP wastewater systems.

\section{Materials and methods}

\section{Sampling}

In this study, wastewater from a PRF-WW, an MSWP and inflow of a WWTP were tested. The locations of the sampling points are shown in Fig. 1. All samples were collected in precleaned glass amber bottles $(1 \mathrm{~L})$ and transported to the laboratory under dark conditions at $4 \pm 1{ }^{\circ} \mathrm{C}$.

\section{Landfill leachates}

In this study, LLs were collected from a modern cell (MP-LLs) and a previous cell (PP-LLs) of a MSWP situated in the Pomerania region (northern Poland). The previous cell, exploited from January 2003 to November 2011, was operated with unlimited disposal of organic wastes, while the disposal of biodegradable wastes in the modern prism (in operation since 2011), due to legislative requirements, is only partly permitted. Along with other EU members, Poland, which landfilled more than $80 \%$ of its municipal waste in 1995 , was required by Directive 1999/31/EC to progressively reduce the landfilling of biodegradable waste to $75 \%$ by $2010,50 \%$ by 2013 , and $35 \%$ by 2020. Thus, the quality of the MP-LLs is expected to differ significantly from that of the PP-LLs (for details, see FudalaKsiazek et al. 2016).

The studied MSWP serves a metropolitan area with a population of approximately 460,000 people and receives ca. 190,000 tons of waste per year, of which 97,000 tons is biodegradable. Samples were collected monthly from January 2015 to April 2016 as 24-h composite samples. In total, 20 samples were collected.

\section{Wastewater from cruise ships}

The wastewater from cruise ships and ferries was collected in the Port of Gdynia (northern Poland) during the tourist seasons of 2015 and 2016 (from April to October). Samples of raw (RMTWW) and pretreated (PMT-WW) wastewater were collected from port reception facilities (PRF-WW) during the emptying of the wastewater tanks (the middle stream). In total, 25 wastewater samples were collected, and 15 of the samples had been pretreated in wastewater treatment plants on cruise ships (PMT-WWs). The onboard treatment systems were not reported, just the wastewater status (raw or pretreated). The RMT-WW samples consisted of a mixture of black water (water from toilets) and grey water (other
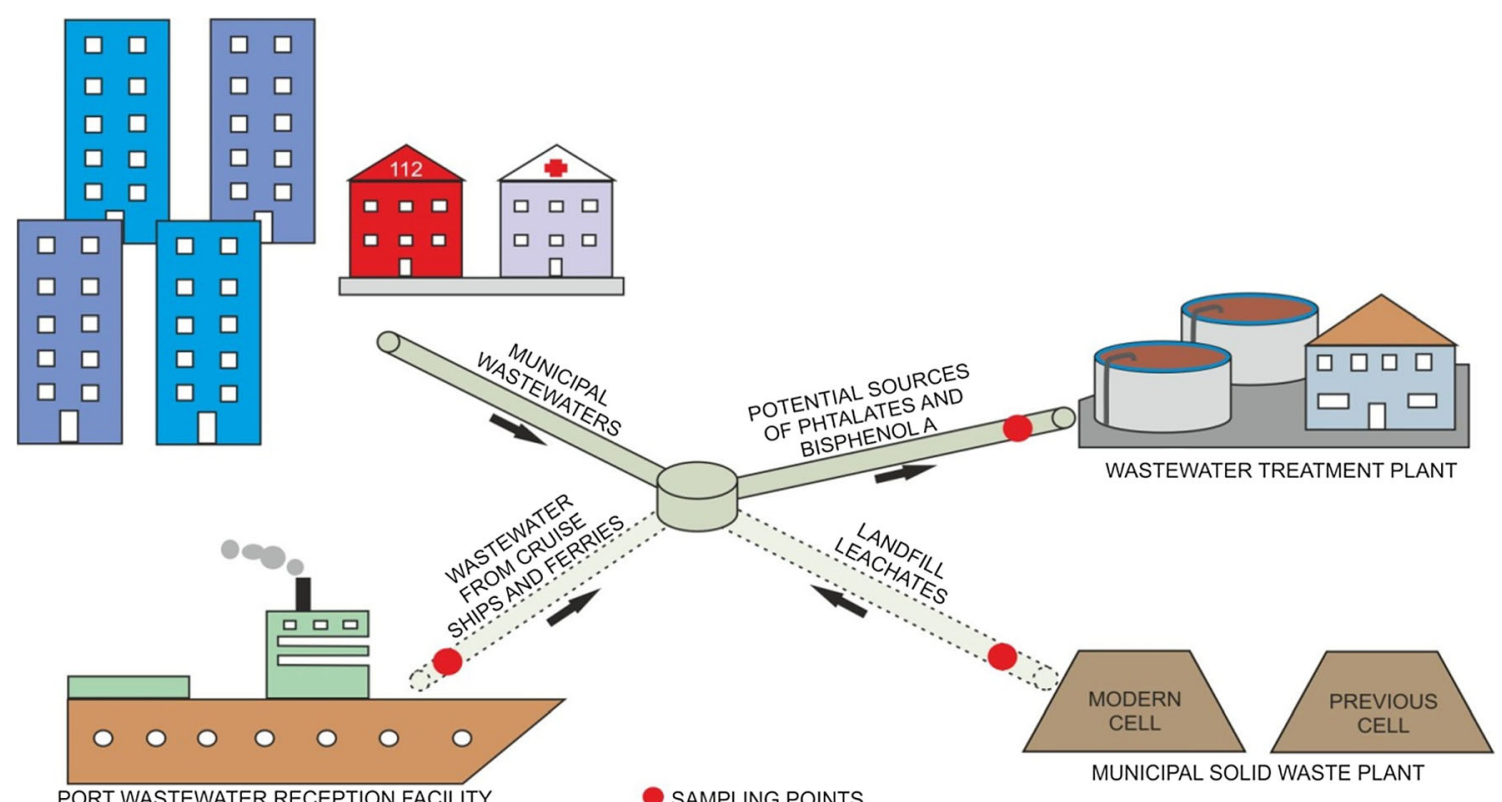

Fig. 1 Locations of sampling points: influent of wastewater treatment plant (IN-WWTP); landfill leachates generated by a modern cell (MPLLs) that meets EU requirements and a previous cell (PP-LLs) with unlimited disposal of biodegradable wastes; wastewater from cruise ships and ferries: raw (RMT-WW) and pretreated onboard (PMT-WW); solid lines represent existing connections and dashed lines represent planned connections between the port reception facilities (PRF-WW) and municipal solid waste plant (MSWP) and the local wastewater treatment plant (WWTP) 
types of wastewaters generated by kitchens, showers, sinks, laundry, and other sources aboard the cruise ships).

\section{Municipal wastewater}

Samples of municipal wastewater were collected twice a month from January 2015 to December 2016 from the inflow of the WWTP Gdynia-Debogorze (IN-WWTP), northern Poland. In total, 48 samples were collected.

The population equivalent (PE) served by WWTP GdyniaDebogorze is equal to $440,000\left(Q_{\mathrm{av}}=55,000 \mathrm{~m}^{3} /\right.$ day $)$, and its technology consists of mechanical and biological treatment (advanced biological nutrient removal), secondary settling tanks with recirculation of excess sludge, and a chemical system (iron(II) chloride; PIX dosing) for occasional phosphorus removal. Currently, industrial wastewater (mostly from the food industry) contributes $10 \%$ of the total wastewater inflow; however, in the near future, the WWTP is planned to receive LLs from the nearby MSWP and wastewater from the PRFsWW in the Port of Gdynia.

\section{Chemical analysis}

\section{Basic physical and chemical analyses}

Among the routinely measured parameters, the following parameters were analysed according to the American Public Health Association (APHA 2005): $\mathrm{pH}$ and conductivity (by a portable multi-parameter meter, the HL-HQ40d multi, $\mathrm{HACH}$, Germany); inorganic $\mathrm{N}$ compounds $\left(\mathrm{N}-\mathrm{NH}_{4}, \mathrm{~N}-\right.$ $\mathrm{NO}_{3}$, and $\mathrm{N}-\mathrm{NO}_{2}$ ), total phosphorus (TP), orthophosphate $\left(\mathrm{P}-\mathrm{PO}_{4}\right)$, chemical oxygen demand (COD), chloride $\left(\mathrm{Cl}^{-}\right)$, sulfate $\left(\mathrm{SO}_{4}{ }^{2-}\right)$, and sulfides $\left(\mathrm{S}^{2-}\right)$ using a XION 500 spectrophotometer (Dr. Lange, GmbH, Germany); 5-day biochemical oxygen demand $\left(\mathrm{BOD}_{5}\right)$ using the manometric respirometric BOD OxiTop® method; and total suspended solids (TSS) using the gravimetric method.

\section{Analysis of phthalates (PAEs) and bisphenol A (BPA)}

Selected PAEs (DMP — dimethyl phthalate, DEP — diethyl phthalate, DnBP — di-n-butyl phthalate, BBzP - benzyl butyl phthalate, DEHP — bis(2-ethylhexyl) phthalate, and DnOP — din-octyl phthalate) and BPA were determined by gas chromatography mass spectrometry (GC-MS) after prior liquid-liquid extraction to mixture of acetonitrile and tetrahydrofuran in a ratio of $4 / 1(v / v)$ in the presence of inorganic salts (for details, please see Fig. S1, Supplementary Material). The GC-MS analyses were performed on a semi-polar ZB-5MS column in split mode. The ion energy for electron impact (EI) was $70 \mathrm{eV}$, and mass detection was performed in the single-ion monitoring (SIM) mode accordingly to Fudala-Ksiazek et al. (2017). The selected ions $(\mathrm{m} / \mathrm{z})$ and retention times used for qualitative and quantitative purposes are shown in Table S2 (Supplementary Material). From 15 samples of PMR-WW, 5 were excluded from micropollutant analyses due to the possible improper onboard management of wastewater treatment plants (see the 'Results and Discussion' section). The LLs were also tested for the presence of BPA and PAE: 8 samples of PP-LLs and 9 samples of MP-LLs. Additionally, 6 samples of IN-WWTP were analysed.

\section{Quality assurance and quality control (QA/QC)}

All data were subjected to precise quality control procedures. External calibration curves (mixture of all selected analytes: DMP, DEP, DnBP, BBzP, DEHP, DnOP, BPA) were used for quantitative analyses. Linearity was checked in the range 10$100 \mu \mathrm{g} / \mathrm{L}\left(r^{2}>0.995\right.$ for all analytes $)$. Measurements of samples were performed in triplicate. All sample processing steps of the analytical method were included in the determination of the method detection limit. The method detection limits (LOD) for each analyte were calculated based on the standard deviation of the response $(s)$ and the slope of the calibration curve $(b)$ according to the formula LOD $=3.3(s / b)$. Method quantification limits (LOQ) were calculated according to the formula $L O Q=3$ LOD. The accuracy and precision of the measurements (in \%) of individual analytes are presented in Table 1. Blank (acetonitrile and tetrahydrofuran in a ratio of 4/ $1(v / v)$ ) and reference solutions (analyte standard solution concentration $-200 \mu \mathrm{g} / \mathrm{L})$ were run after every ten samples to ensure the precision of the determination of the analytes in each sequence. Moreover, procedure blanks were analysed in the same setup as the samples, using the same reagents, in de-ionized water with levels below the detection limit for each analyte. Moreover, the matrix effect of landfill leachates and wastewaters has been checked through. Selected samples have been spiked by analytes (concentrations were $50 \mu \mathrm{g} / \mathrm{L}$ for DMP, DEP, DnBP, BBzP, DEHP, and DnOP and $735 \mu \mathrm{g} / \mathrm{L}$

Table 1 Basic quality control parameters for GC-MS analysis

\begin{tabular}{lllll}
\hline Analyte & LOD $[\mu \mathrm{g} / \mathrm{L}]$ & LOQ $[\mu \mathrm{g} / \mathrm{L}]$ & Recovery $^{\mathrm{a}}[\%]$ & RSD $^{\mathrm{a}}[\%]$ \\
\hline DMP & 2.30 & 7.68 & 100 & 6.4 \\
DEP & 6.08 & 20.3 & 116 & 8.8 \\
DnBP & 16.1 & 53.6 & 92.9 & 7.8 \\
BBzP & 0.30 & 1.00 & 79.2 & 12 \\
DEHP & 44.8 & 149 & 55.6 & 4.8 \\
DnOP & 1.20 & 4.00 & 47.4 & 8.3 \\
BPA & 37.5 & 125 & 135 & 7.0 \\
\hline
\end{tabular}

$L O D$ limit of detection, $L O Q$ limit of quantification, $R S D$ relative standard deviation, $D M P$ dimethyl phthalate, $D E P$ diethyl phthalate, $D n B P$ di-n-butyl phthalate, $B B z P$ benzyl butyl phthalate, $D E H P$ bis(2ethylhexyl) phthalate, $D n O P$ di-n-octyl phthalate, $B P A$ bisphenol A

${ }^{\mathrm{a}}$ Refers to the standard solution with a concentration of $50 \mu \mathrm{g} / \mathrm{L}$ for each analyte 
for BPA). The variation between spiked samples (with matrix) and the standard solution (without matrix) was less than $10 \%$.

\section{Statistical analysis}

Data spreadsheets were prepared using Microsoft Excel® 2016 (Microsoft, 2016, USA). Statistical analyses (Fig. 2) were carried out using Statistica 12 (StatSoft, Inc.) software. The distributions of the pollutant concentrations and the basic values of the descriptive statistics are shown using box plots (minimum, maximum, upper quartile, lower quartile, median values, outliers and extreme values). Box plots represent the symmetry or asymmetry of the data well and allow the visualization of the variability among the compared groups. The normality of the data was determined with the Shapiro-Wilk test, while the homogeneity of the variance was assessed with Levene's test. For all the tests, differences were determined to be statistically significant if $p<0.05$. The non-parametric Wilcoxon's signed rank test was used to compare the concentration of contaminants in RMT-WWs and PMT-WWs. The Mann-Whitney $U$ test was used to indicate the significance of differences between the values of pollutant concentrations in MP-LLs and PP-LLs.
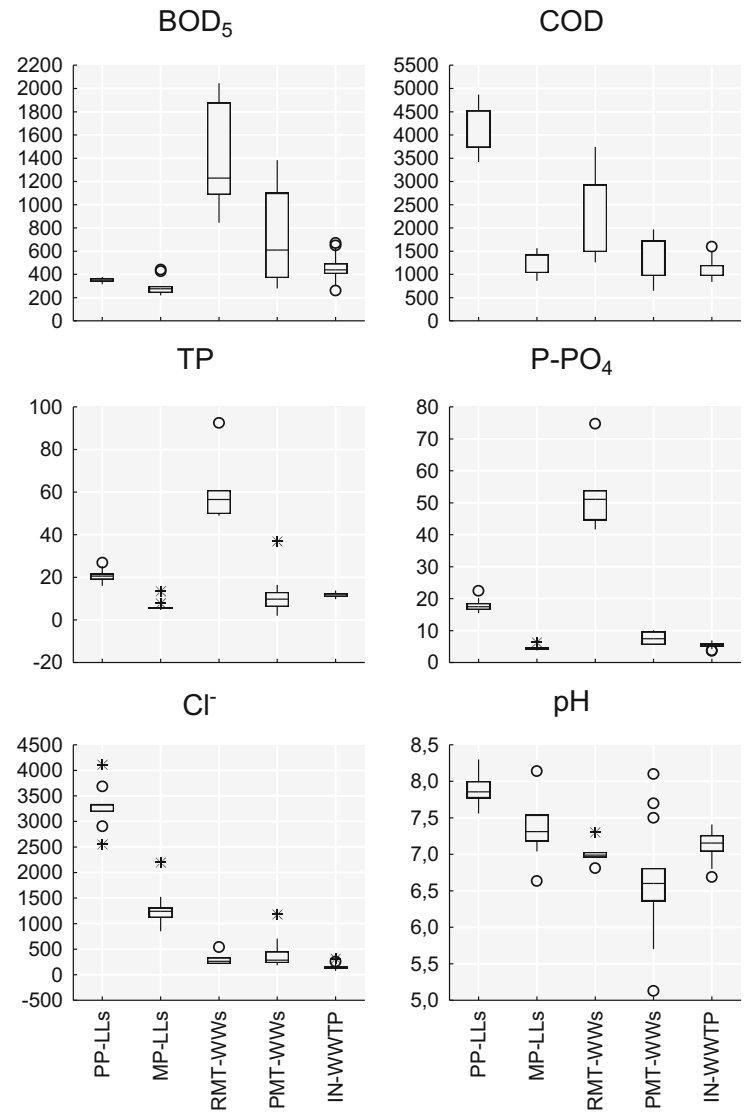

Fig. 2 Minimum, maximum, upper quartile, lower quartile, median values, outliers, and extreme values for the parameters of sewage contamination and $\mathrm{BOD}_{5} / \mathrm{COD}$ and $\mathrm{BOD}_{5} / \mathrm{TN}$ for the leachates

\section{Results and discussion}

The wastewater that originates from different municipal services is often discharged to municipal wastewater systems, either directly or after onsite pretreatment. Unfortunately, the discharge requirements are limited to the routinely measured parameters used to characterize the wastewater, such as $\mathrm{BOD}_{5}$, COD, TSS, TN, and TP (see Table S2 for comparison). Other specific contaminants, such as micropollutants, are not routinely tested. Thus, in this study, the presence of BPA and PAEs, regarded as endocrine-disrupting compounds, was determined in the wastewater generated by municipal services, such as MTWWs (PMT-WWs and RMT-WWs) from cruise ships calling at the Port of Gdynia and LLs (MP-LLs and PP-LLs) from MSWPs. Due to the planned discharge of LLs and MT-WWs to local municipal wastewater systems, the inflow into the WWTP Gdynia-Debogorze was also analysed (IN-WWTP) to obtain the current baseline conditions (Fig. 1).

\section{Physico-chemical results}

According to the obtained results, the quality of MP-LLs generated by the modern cell (meeting current EU requirements in
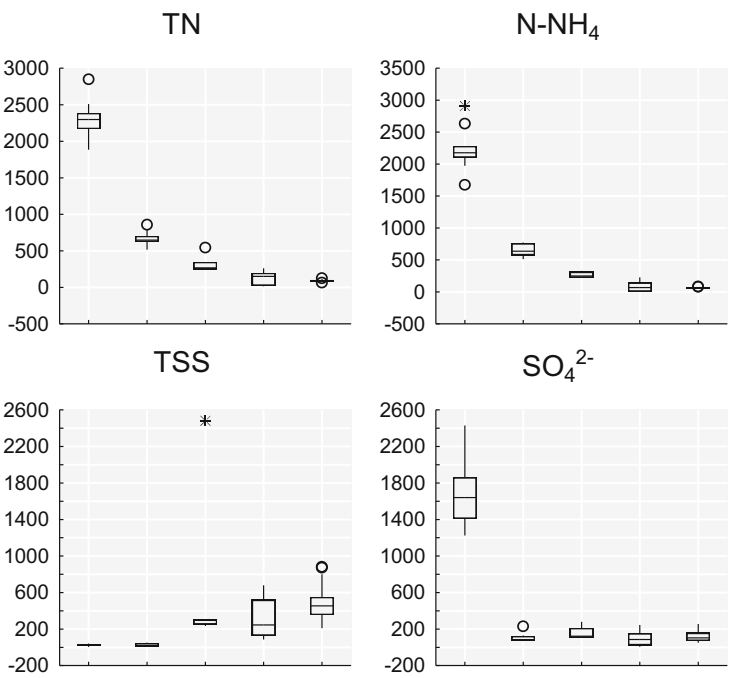

BOD5/COD
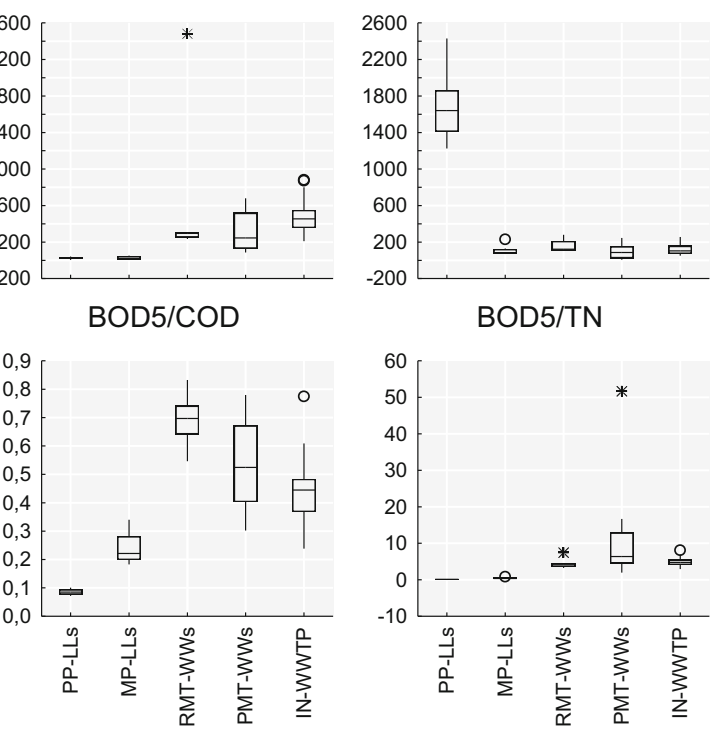

generated by the previous (PP-LLs) and modern (MP-LLs) cells, raw (RMT-WWs) and pretreated wastewater (PMT-WWs) from cruise ships and ferries, and municipal wastewater entering the WWTP (IN-WWTP) 
terms of waste management and disposal) and the quality of PP-LLs generated by the previous cell (exploited without any limits) differ significantly (Table 2; for a detailed description, also see Supplementary Materials).

The Mann-Whitney $U$ test revealed that there was a significant difference $(p<0.05)$ in the mean pollutant concentrations between the MP-LLs and the PP-LLs. Higher pollutant concentrations were found in the PP-LLs, except for $\mathrm{BOD}_{5}$ and TSS values, due to the generation of the methane phase (Fudala-Ksiazek et al. 2016, 2017). This finding was confirmed indirectly by the stable methane production (personal communication, exploiter at studied MSWP), low $\mathrm{BOD}_{5} /$ COD ratio $(0.090 \pm 0.008)$, and $\mathrm{COD}$ and $\mathrm{BOD}_{5}$ values $\left(4120 \pm 11 \mathrm{mg} \mathrm{O}_{2} / \mathrm{L}\right.$ and $351 \pm 21 \mathrm{mg} \mathrm{O}_{2} / \mathrm{L}$, respectively), with a small coefficient of variation $\left(V_{\mathrm{COD}}=11.3 \%\right.$, $V_{\mathrm{BOD} 5}=5.9 \%$ ). In the case of MP-LLs, the following average values of COD were determined: $1248 \pm 236 \mathrm{mg} \mathrm{O} / 2$ $\left(V_{\mathrm{COD}}=18.9 \%\right)$ and $\mathrm{BOD}_{5} 297 \pm 76 \mathrm{mg} \mathrm{O} / \mathrm{L}\left(V_{\mathrm{BOD} 5}=\right.$ $25.6 \%$ ). The average $\mathrm{BOD}_{5} / \mathrm{COD}$ ratio in MP-LLs was equal to $0.33 \pm 0.24$, indicating the presence of readily biodegradable compounds in a total pool of organic matter.

Phosphorus in both the PP-LLs and MP-LLs occurred mainly as $\mathrm{P}_{-} \mathrm{PO}_{4}$. In the MP-LLs, $\mathrm{P}-\mathrm{PO}_{4}$ accounted for $84.9 \% \pm 4.0 \%$ of the TP, while in the PP-LLs, it accounted for $69.0 \% \pm 13.0 \%$ of the TP (Fig. 2). The TN in the PP-LLs reached $2296 \pm 264 \mathrm{mg} \mathrm{N} / \mathrm{L}\left(V_{\mathrm{TN}}=11.5 \%\right)$, while the $\mathrm{TN}$ in MP-LLs was much lower, with a value of $670 \pm 97 \mathrm{mg} \mathrm{N} / \mathrm{L}$ $\left(V_{\mathrm{TN}}=14.5 \%\right)$. In both cells, nitrogen was released mainly in the mineral form of ammonia and was equal to $2231 \pm 340 \mathrm{mg}$ $\mathrm{N}-\mathrm{NH}_{4} / \mathrm{L}\left(V_{\mathrm{N}-\mathrm{NH} 4}=15.2 \%\right)$ in the PP-LLs and $649 \pm 93 \mathrm{mg}$ $\mathrm{N}-\mathrm{NH}_{4} / \mathrm{L}\left(V_{\mathrm{N}-\mathrm{NH} 4}=14.4 \%\right)$ in the MP-LLs. The significantly higher nitrogen content in the PP-LLs than in the MP-LLs can again be explained by the unlimited disposal of biodegradable waste during the period of the previous cell exploitation.

Typically, in LLs, high conductivity and the presence of chloride and sulfate ions are also usually noted (Fan et al. 2006; Kawai et al. 2012), which was confirmed by the present study.

The pollution load of the LLs was significant, even when compared with the raw wastewater generated by cruise ships (RMT-WWs), and both were much more concentrated than municipal wastewater (IN-WWTP). The high pollution load in the RMT-WWs may be a result of the limited water volume used onboard (Fig. 2). In this study, the tested RMT-WW samples were a mixture of black water and grey water, and their parameters varied in wide ranges, e.g., TSS from 234 to $2483 \pm 885 \mathrm{mg} / \mathrm{L}, \mathrm{COD}$ from 1260 to $3744 \pm 862 \mathrm{mg} \mathrm{O} / \mathrm{L}$,

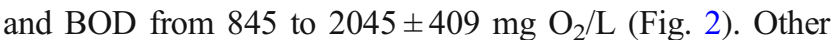
authors also reported a high variability in raw wastewater generated by cruise ships (Prior 2013; King County Wastewater Treatment Division 2007). This variability is mainly caused by the different onboard services offered (e.g., restaurants, spas, swimming pools, and bars), cruise duration, and, within some assumed limits, the number of passengers on board. However, due to the low $\mathrm{COD} / \mathrm{BOD}_{5}$ ratio $(<1.8)$, RMT-WWs can be regarded as susceptible to biological degradation. The high nitrogen and phosphorus concentrations are noteworthy (TN up to $544 \mathrm{mg} \mathrm{N} / \mathrm{L}$ and TP up to $92.4 \mathrm{mg} \mathrm{P} / \mathrm{L}$ ) in RMT-WWs, with average high proportions of ammonia $(84.0 \%)$ and phosphates $(87.0 \%)$. The obtained values of $\mathrm{N}-\mathrm{NH}_{4}(226-332 \mathrm{mg} / \mathrm{L})$ and $\mathrm{P}^{-\mathrm{PO}_{4}}$ $(41.7-74.8 \mathrm{mg} / \mathrm{L})$ were much higher in RMT-WWs than the values typically observed in municipal sewage (Heinrich and Kozak 2009). The presence of phosphorus is most likely a result of the considerable amount of cleaning agents used in different services offered by cruise ships, as confirmed by Wilewska-Bien et al. (2018). Additionally, the spa facilities often offer brine baths and use chemical water softeners, and in some ships, seawater is used for flushing the toilets, which can explain the high concentrations of sulfate and chloride $\left(162 \pm 62 \mathrm{mg} \mathrm{SO}_{4}{ }^{2-} / \mathrm{L}, 299 \pm 107 \mathrm{mg} \mathrm{Cl}^{-} / \mathrm{L}\right)$ noted in the RMT-WWs in this study. Moreover, TSS especially varied across a wide range in the RMT-WWs, from 234 to $2488 \mathrm{mg} / \mathrm{L}$, but values up to $9660 \mathrm{mg} \mathrm{TSS} / \mathrm{L}$ have also been reported (Mróz 2017; Sun et al. 2010a, 2010b). The average $\mathrm{pH}$ value of raw sewage was $7.00 \pm 0.13$, and the variability of the obtained values in the tested samples was small $\left(V_{\mathrm{pH}}=\right.$ $1.9 \%)$.

Because the Baltic Sea is particularly susceptible to eutrophication and is regarded by MARPOL as a special area for wastewater discharge (Cruise Baltic 2017; Kovalevskiene et al. 2017; Perić et al. 2016), special attention should be paid to limit the excess inflow of biogenic substances into the sea (Pihlajamäki and Tynkkynen 2011). According to the obtained results, the tested RMT-WWs indicated the possibility for nitrogen $\left(315 \pm 112 \mathrm{mg} \mathrm{TN} / \mathrm{L}, V_{\mathrm{TN}}=31.0 \%\right)$ removal via biological methods because the average $\mathrm{BOD}_{5} / \mathrm{TN}$ ratio $(4.0 \pm$ $\left.0.4 \mathrm{~g} \mathrm{BOD}_{5} / \mathrm{g} \mathrm{TN}\right)$ was higher than the level necessary to support denitrification with organic carbon $\left(3.5 \mathrm{~g} \mathrm{BOD}_{5} / \mathrm{g}\right.$ TN) (Swinarski et al. 2009) (Fig. 2). Thus, onboard wastewater treatment is usually based on biological degradation (Sun et al. 2010a, 2010b) and membrane separation (membrane bioreactor system, MBR); these treatments meet the MARPOL Convention standards for phosphorus and nitrogen removal (MEPC.227(64) 2012). Interestingly, in some cases, the quality of cruise ship wastewater that was reported as pretreated onboard (PMT-WW) differed considerably from the limits required by the MARPOL Convention (Fig. 2). Unsatisfactory adherence to the levels of the routinely measured parameters by onboard wastewater treatment facilities is surprising because, according to a personal communication (Technical Ship Management 2019, Sp. z o.o.), most of the cruise ships are equipped with advanced MBR systems. For instance, in some of the PTM-WW samples tested in this study, parameters such as COD $(647-1970 \mathrm{mg} \mathrm{O} / \mathrm{L}), \mathrm{BOD}_{5}$ (280-1384 $\left.\mathrm{mg} \mathrm{O}_{2} / \mathrm{L}\right), \mathrm{TN}(22.7-261 \mathrm{mg} / \mathrm{L}), \mathrm{N}^{-N_{4}}{ }_{4}(2.8-$ $228 \mathrm{mg} / \mathrm{L}), \mathrm{TP}(1.9-36.9 \mathrm{mg} / \mathrm{L}), \mathrm{P}^{-} \mathrm{PO}_{4}(5.6-10.1)$, and $\mathrm{Cl}^{-}$ 
Table 2 Presence of PAEs and BPA in LLs generated by previous (PP-LL) and modern (MP-LL) cells, raw (RMT-WW) and pretreated (PMT-WW) wastewater generated by cruise ships and ferries, and municipal wastewater (IN-WWTP) entering the WWTP

\begin{tabular}{|c|c|c|c|c|c|}
\hline \multirow[t]{2}{*}{ Parameters $[\mu \mathrm{g} / \mathrm{L}]$} & \multicolumn{2}{|c|}{ Landfill leachates } & \multicolumn{2}{|c|}{ Cruise ships and ferries ${ }^{\mathrm{a}}$} & \multirow{2}{*}{$\begin{array}{l}\text { MWTP } \\
\text { IN-WWTP }\end{array}$} \\
\hline & PP-LLs & MP-LLs & RMT-WWs & $\begin{array}{l}\text { PMT- } \\
\text { WWs }\end{array}$ & \\
\hline DMP & $\begin{array}{l}<\text { LOD-27.9 } \\
6 / 1 / 1\end{array}$ & $\begin{array}{l}<\text { LOD-23.1 } \\
4 / 4 / 1\end{array}$ & $\begin{array}{l}<\text { LOD-118 } \\
3 / 4 / 3\end{array}$ & $\begin{array}{l}<\mathrm{LOD} \\
10 / 0 / 0\end{array}$ & $\begin{array}{l}<\mathrm{LOD} \\
6 / 0 / 0\end{array}$ \\
\hline DEP & $\begin{array}{l}<\mathrm{LOD},<\mathrm{LOQ} \\
7 / 1 / 0\end{array}$ & $\begin{array}{l}<\text { LOD }-46.2 \\
5 / 2 / 2\end{array}$ & $\begin{array}{l}<\text { LOD }-43.7 \\
2 / 4 / 4\end{array}$ & $\begin{array}{l}<\text { LOD } \\
10 / 0 / 0\end{array}$ & $\begin{array}{l}<\mathrm{LOD},<\mathrm{LOQ} \\
5 / 1 / 0\end{array}$ \\
\hline $\mathrm{DnBP}$ & $\begin{array}{l}<\text { LOD } \\
8 / 0 / 0\end{array}$ & $\begin{array}{l}<\text { LOD } \\
9 / 0 / 0\end{array}$ & $\begin{array}{l}<\mathrm{LOD} \\
10 / 0 / 0\end{array}$ & $\begin{array}{l}<\text { LOD } \\
10 / 0 / 0\end{array}$ & $\begin{array}{l}<\mathrm{LOD} \\
6 / 0 / 0\end{array}$ \\
\hline $\mathrm{BBz} P$ & $\begin{array}{l}<\mathrm{LOD} \\
8 / 0 / 0\end{array}$ & $\begin{array}{l}<\text { LOD-1.7 } \\
8 / 0 / 1\end{array}$ & $\begin{array}{l}<\mathrm{LOD} \\
10 / 0 / 0\end{array}$ & $\begin{array}{l}<\mathrm{LOD} \\
10 / 0 / 0\end{array}$ & $\begin{array}{l}<\mathrm{LOD} \\
6 / 0 / 0\end{array}$ \\
\hline DEHP & $\begin{array}{l}<\mathrm{LOD}-257 \\
4 / 1 / 3\end{array}$ & $\begin{array}{l}<\text { LOD-536 } \\
6 / 2 / 1\end{array}$ & $\begin{array}{l}<\text { LOD-738 } \\
1 / 4 / 5\end{array}$ & $\begin{array}{l}<\mathrm{LOD} \\
10 / 0 / 0\end{array}$ & $\begin{array}{l}<\mathrm{LOD},<\mathrm{LOQ} \\
3 / 3 / 0\end{array}$ \\
\hline $\mathrm{DnOP}$ & $\begin{array}{l}<\mathrm{LOD} \\
8 / 0 / 0\end{array}$ & $\begin{array}{l}<\mathrm{LOD} \\
9 / 0 / 0\end{array}$ & $\begin{array}{l}<\text { LOQ-52.1 } \\
0 / 6 / 4\end{array}$ & $\begin{array}{l}<\mathrm{LOD} \\
10 / 0 / 0\end{array}$ & $\begin{array}{l}<\mathrm{LOD} \\
6 / 0 / 0\end{array}$ \\
\hline BPA & $\begin{array}{l}856-2202 \\
0 / 0 / 8\end{array}$ & $\begin{array}{l}<\text { LOQ-150 } \\
0 / 6 / 3\end{array}$ & $\begin{array}{l}145-957 \\
0 / 0 / 10\end{array}$ & $\begin{array}{l}<\text { LOD } \\
10 / 0 / 0\end{array}$ & $\begin{array}{l}<\mathrm{LOD},<\mathrm{LOQ} \\
2 / 4 / 0\end{array}$ \\
\hline
\end{tabular}

$D M P$ dimethyl phthalate, $D E P$ diethyl phthalate, $D n B P$ di-n-butyl phthalate, $B B z P$ benzyl butyl phthalate, $D E H P$ bis(2-ethylhexyl) phthalate, $D n O P$ din-octyl phthalate, $B P A$ bisphenol A

${ }^{\text {a }}$ In this study, 5 out of 15 samples of raw wastewater of maritime transport origin (RMT-WW) were excluded from micropollutant analyses due to the possible improper onboard management of wastewater treatment plants

${ }^{b}$ The first line is the range of micropollutant concentrations. The second line $(<\mathrm{LOD} /<\mathrm{LOQ} />\mathrm{LOQ})$ is the number of samples with the results below the LOD (<LOD), between the LOD and the LOQ, and greater than the LOQ ( $>$ LOQ), respectively (for details, see Table 1)

(190-1184 mg/L) were equal to or greater than those of the raw municipal wastewater (IN-WWTP) (Fig. 2). Thus, the quality of the wastewater declared by ship owners as pretreated (PMT-WW) was questionable in many cases (Fig. 2), suggesting improper management of onboard wastewater treatment plants.

\section{Micropollutants}

For the tested endocrine disruptors, the LLs were expected to be the most important source of PAEs and BPA among the analysed samples because both substances are used in numerous products that generally end up in wastewater or solid waste streams. However, according to the obtained results, raw wastewater generated by cruise ships (RMT-WWs) was significantly more polluted with PAEs and BPA than the LLs.

In the case of LLs, a significant difference in PAE and BPA concentrations was observed between the MP-LLs and the PP-LLs undoubtedly caused by the limitations imposed by the EU regulations (Directive 2018/850/EU amending Directive 1999/31/EC) on the deposition of biodegradable and recycled materials in modern cells (MP-LLs) (Table 2 and Table S3 in Supplementary Materials). Thus, the level of BPA in the MP-LLs varied from below the limit of quantification (<LOQ) up to $150 \mu \mathrm{g} / \mathrm{L}$, while in the PP-LLs, it reached $2202 \mu \mathrm{g} / \mathrm{L}$. High BPA concentrations in municipal LLs were also noted by others and ranged from 26 to
$8400 \mu \mathrm{g} / \mathrm{L}$ (Urase and Miyashita 2003; Morin et al. 2015; Teuten et al. 2009).

In LLs, the presence of PAEs and BPA is mainly connected with their release from parent products (especially low molecular weight phthalates such as DMP and DEP) and with biodegradation. In the study by Schwarzbauer et al. (2002), the observed BPA values were 4,200-25,000 $\mu \mathrm{g} / \mathrm{L}$, while a Norwegian survey reported BPA concentrations in the range of $1-62 \mu \mathrm{g} / \mathrm{L}$ (Arp et al. 2017). On the other hand, Kurata et al. (2008), who examined the leachate from 38 landfills in Japan, determined the maximum BPA value to be $3600 \mu \mathrm{g} / \mathrm{L}$. The results presented also show that BPA is potentially one of the most frequent micropollutants found in LLs. It should be noted that the BPA values in LLs depend on many factors, such as landfill cell age, the type of waste deposited, and the way the landfill site is operated (Kulikowska 2009).

In the case of PAEs, the highest maximum concentrations in the LLs were associated with DEHP, DMP, and DEP, with values up to $536 \mu \mathrm{g} / \mathrm{L}, 27.9 \mu \mathrm{g} / \mathrm{L}$, and $46.2 \mu \mathrm{g} / \mathrm{L}$, respectively. According to this and other studies, DEHP, which was classified as a Category 1B reprotoxin by the European Union's REACH legislation, is the most frequently observed PAE in LLs (Asakura et al. 2004; Zhang and Wang 2009). Wowkonowicz and Kijeńska (2017) detected DEHP $<1.3$ to $73.9 \mu \mathrm{g} / \mathrm{L}$ and DMP $<0.6$ to $1.98 \mu \mathrm{g} / \mathrm{L}$ to $4.72 \mu \mathrm{g} / \mathrm{L}$ in $\mathrm{LLs}$ generated by an old cell located in central Poland. Kalmykova 
et al. (2013) reported that DEHP concentrations in LL samples ranged from $<1.0$ to $23 \mu \mathrm{g} / \mathrm{L}$ and that DEP concentrations ranged from $<0.10$ to $22 \mu \mathrm{g} / \mathrm{L}$, while DnOP and DnBP were not detected.

In the case of MT-WW, Westhof et al. (2016) reported that PAEs and BPA occur mainly in grey water, while pharmaceuticals are predominant in black wastewater (Nödler et al. 2014). In this study, the presence of 4 out of the 6 analysed PAEs was noted in RMT-WWs discharged from ships (Table 2). DnBP and BBzP were not detected in the analysed samples (LOD $<16.1 \mu \mathrm{g} / \mathrm{L}$ and $\mathrm{LOD}<0.3 \mu \mathrm{g} / \mathrm{L}$, respectively; for details, see Table 1 and Table 2), while BPA, DEHP, DMP, DnOP, and DEP were detected at maximum concentrations of $957 \mu \mathrm{g} / \mathrm{L}, 738 \mu \mathrm{g} / \mathrm{L}, 118 \mu \mathrm{g} / \mathrm{L}, 52.1 \mu \mathrm{g} / \mathrm{L}$, and $43.7 \mu \mathrm{g} / \mathrm{L}$, respectively (Table 2 ). High concentrations of BPA and PAEs in RMT-WWs can be explained by their abundance in products that are in everyday use onboard the ship (e.g., plastic bottles and containers). The ship restaurants and services also utilize and process food in synthetic packaging, which increases direct (ingestion) and indirect (respiratory system and dermal exposure) consumption and excretion of BPA and PAEs (Westhof et al. 2016; Crain et al. 2007). Among PAEs, the highest concentration in RMT-WWs was detected for DEHP and DMP. DMP is often present in non-plastic products such as pharmaceuticals and personal care products (Bui et al. 2016; Larsson et al. 2017). DMP is of concern because the growing demand for beauty services has caused even smaller and older cruise ships to offer the highest-quality beauty salons (hair/barber and nail stylists) and spa services (aqua-spas, body wraps, mud baths, body and facial massages, etc.). All of the abovementioned facilities utilize products that contain both PAEs and BPA.

On the other hand, DEHP, BBzP, and DnBP, which were confirmed to cause the so-called phthalate syndrome in animals (e.g., cryptorchidism, hypospadias, and shortened anogenital distance) (Foster et al. 2000; Gray Jr et al. 2000; Mylchreest et al. 2000) and are suspected to similarly affect humans (Suzuki et al. 2011; Swan et al. 2005), have already been prohibited in toys, childcare articles, and cosmetic products (EC No 1223/2009; Directive 2005/84/EC). Thus, the noticeable presence of DEHP in current RMT-WWs is surprising and requires future study.

Fortunately, both PAEs and BPA were below detection limits (<LOD) in PMT-WWs, which may confirm that the onboard MBR systems are effective in removing these tested compounds. In the literature (Judd 2008; Karim and Mark 2017; Mitra et al. 2016), however, the opinion regarding the effectiveness of MBR reactors in micropollutant removal varies, which is probably a result of the membrane system used in MBR (micro/ultrafiltration) and/or the compounds under consideration.
Nevertheless, further research is required because knowledge on the fate of micropollutants generated by maritime transport is limited.

In this study, PAEs and BPA were also tested in the wastewater currently entering the local WWTP (INWWTP) due to the planned connection of municipal wastewater systems with wastewater streams generated at the local MSWP and collected by PRF-WW. The obtained results did not reveal the presence of PAEs and BPA in the IN-WWTP in quantifiable concentrations (Fig. 3).

In the context of industrial wastewater treatment, the presence of contaminants discharged into the municipal wastewater system that may pass untreated through the WWTPs and have a negative impact on the receiving waters should be considered. For this reason, in the current study, proper approaches to the management of industrial wastewaters originating from municipal services (LLs and in MT-WWs) and the municipal wastewater system are crucial (cleaner production and end-of-pipe technology). Every year, approximately $2700 \mathrm{~m}^{3}$ of leachate is generated by the studied MSWP and is currently directed to the onsite pretreatment reverse osmosis (RO) installation. However, although RO plants can be effective at removing micropollutants from LLs, this technology unfortunately also generates many operational difficulties. Major problems also occur with concentrate management (Fudala-Ksiazek et al. 2016, 2017, 2018) and during intense rainfall events (mainly in spring and early autumn), when a large LL stream is directed to the municipal wastewater system without pretreatment, due to the limited flow that the RO plant can handle. In addition, the discharge of MT-WW generated by cruise ships and ferries to the Port of Gdynia reception facilities is estimated to exceed $4598.9 \mathrm{~m}^{3}$ per year (Mróz 2017). However, while wastewater pretreated in onboard MBR installations (PMT-WWs) was free of PAEs and BPA, their concentrations in raw wastewater (RMT-WWs) were generally higher than those in the LLs tested in this study. Thus, taking into consideration the environmental sustainability of receiving waters and current baseline conditions (lack of PAEs and BPA in IN-WWTP), a strategic perspective in municipal wastewater management is needed.

Such efforts are of high importance because BPA and PAE removal in activated sludge systems varied widely from 81 to 99\% for BPA and 20 to $93 \%$ for PAEs, with biodegradation and sorption strongly influenced by operational conditions (hydraulic retention time, solids retention time, wastewater temperature, etc.) (Besha et al. 2017; Grandclement et al. 2017; Hale 2003; Luo et al. 2014; Roslev et al. 2007). For this reason, endocrine disruptors can be discharged via treated wastewater in concentrations of environmental significance. 
Fig. 3 Maximum concentrations of PAEs (phthalates: DMPdimethyl phthalate, DEPdiethyl phthalate, DnBP - di-nbutyl phthalate, BBzP — benzyl butyl phthalate, DEHP — bis(2ethylhexyl) phthalate, and DnOP - di-n-octyl phthalate) and BPA (bisphenol A) in landfill leachates generated by previous (PP-LL) and modern (MP-LL) cells, raw (RMT-WW) and pretreated (PMT-WW) wastewater generated by cruise ships and ferries, and municipal wastewater (IN-WWTP) entering the WWTP
10000

$\llbracket \mathrm{DMP} \backsim \mathrm{DEP}\|\mathrm{DnBP} \backsim \mathrm{BBz}=\mathrm{DEHP}\| \mathrm{DnOP} \backsim \mathrm{BPA}$

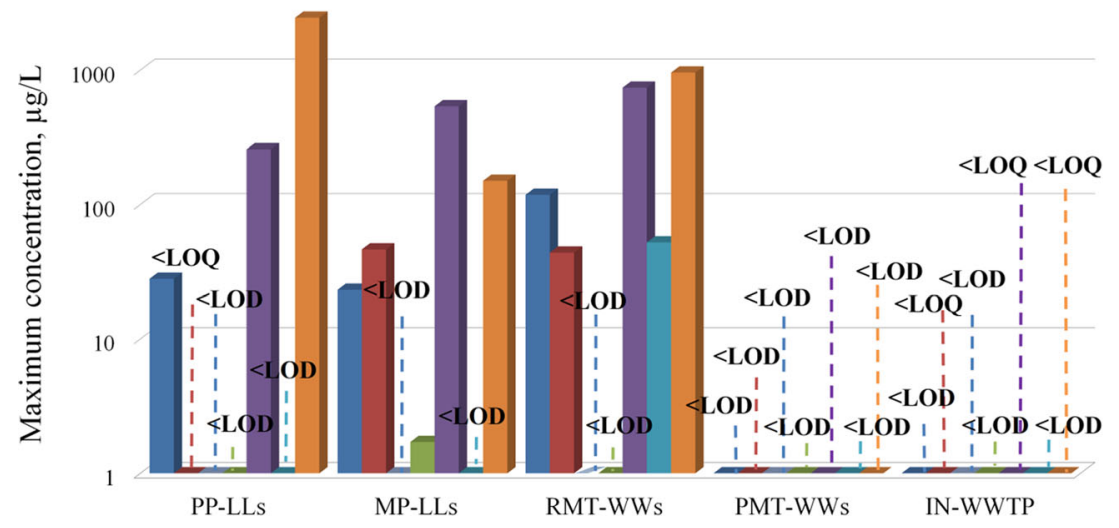

\section{Conclusion}

The presence of micropollutants in the wastewater generated by MSWPs (LLs) and maritime transport (MT-WWs) is crucial if these compounds exhibit limited biodegradability and, after discharge to municipal WWTP, pass untreated as inert organic matter. This situation is of special concern because the final receiver of WWTP effluent is the Baltic Sea coastal area, which, among other uses, is popular for tourism and recreation as well as for professional and recreational fisheries. Based on the obtained results, it can be concluded that the routinely measured parameters of both LLs and RMT-WWs (mixture of raw grey and black sewage) are higher than assumed for municipal wastewater entering a WWTP (INWWTP). These streams are also highly polluted with BPA and PAEs. Special attention should be given to the classified reprotoxin DEHP, which was present in elevated concentrations of up to $257 \mu \mathrm{g} / \mathrm{L}$ in PP-LLs, $536 \mu \mathrm{g} / \mathrm{L}$ in MP-LLs, and $738 \mu \mathrm{g} / \mathrm{L}$ in RMT-WWs. Fortunately, in PMT-WWs and INWWTP, both PAEs and BPA were below detection/ quantification limits $(<\mathrm{LOD} /<\mathrm{LOQ})$. Nonetheless, questions arise regarding sustainable ways to ensure good water status in the future if the MSWP wastewater system and the port reception facility system are to be combined with the municipal wastewater system. Thus, it is essential first to monitor the particular wastewater system to obtain an accurate understanding of the existing impacts that wastewater may have on the sensitive area of the Baltic Sea due to the presence of endocrine disruptors and other micropollutants of concern. Having this knowledge and taking into account local conditions and preferences, the most effective approach can be chosen between onsite pretreatment or end-of-pipe technology.

Acknowledgements The authors gratefully acknowledge the staff of the studied MSWP and PRF-WW for their kind assistance with sampling and for supplying information about the technology. This work was supported by the Regional Fund for Environmental Protection and Water Management in Gdansk, as part of the project entitled Effective removal of micropollutants from wastewater using electrochemical oxidation on nanocrystalline diamond anodes (DIAOPS) (RX-15/13/2017).

Abbreviations BPA, Bisphenol A; BBzP, Butyl benzyl phthalate; DEP, Diethyl phthalate; DnBP, di-n-Butyl phthalate; DEHP, di(2-Ethylhexyl) phthalate; DMP, Dimethyl phthalate; DnOP, Diisodecyl phthalate; INWWTP, Influent of wastewater treatment plant; LLs, Landfill leachates; MP-LLs, Landfill leachates generated by modern cells that meet EU requirements; MSWP, Municipal solid waste plant; MT-WW, Maritime wastewater; PAEs, Phthalates; PP-LLs, Landfill leachates generated by a previous cell operated with unlimited disposal of biodegradable wastes; PRF-WW, Port reception facilities; PMT-WW, Pretreated (onboard) maritime wastewater from a cruise ship; RMT-WW, Raw wastewater from a cruise ship (mixture of grey and black water); WWTP, Wastewater treatment plant

Open Access This article is distributed under the terms of the Creative Commons Attribution 4.0 International License (http:// creativecommons.org/licenses/by/4.0/), which permits unrestricted use, distribution, and reproduction in any medium, provided you give appropriate credit to the original author(s) and the source, provide a link to the Creative Commons license, and indicate if changes were made.

\section{References}

Albergamo V, Blankert B, Cornelissen ER, Hofs B, Knibbe W-J, Meer W, Voogt P (2019) Removal of polar organic micropollutants by pilotscale reverse osmosis drinking water treatment. Water Res 148:535545. https://doi.org/10.1016/j.watres.2018.09.029

APHA-AWWA-WEF (2005) Standard methods for the examination of water and wastewater. APHA-AWWA-WEF, Washington D.C.

Arp HPH, Morin NAO, Hale SE, Okkenhaug G, Breivik K, Sparrevik M (2017) The mass flow and proposed management of bisphenol A in selected Norwegian waste streams. Waste Manag 60:775-785. https://doi.org/10.1016/j.wasman.2017.01.002

Asakura H, Matsuto T, Tanaka N (2004) Behavior of endocrinedisrupting chemicals in leachate from MSW landfill sites in Japan. Waste Manag 24(6):613-622. https://doi.org/10.1016/j.wasman. 2004.02.004 
Badach H, Nazimek TA, Kamińska I (2007) Pesticide content in drinking water samples collected from orchard areas in Central Poland. Ann Agric Environ Med 14:109-114

Besha AT, Gebreyohannes AY, Tufa RA, Bekele DN, Curcio E, Giorno L (2017) Removal of emerging micropollutants by activated sludge process and membrane bioreactors and the effects of micropollutants on membrane fouling: a review. J Environ Chem Eng 5(3):23952414. https://doi.org/10.1016/j.jece.2017.04.027

Boonnorat J, Techkarnjanaruk S, Honda R, Prachanurak P (2016) Effects of hydraulic retention time and carbon to nitrogen ratio on micropollutant biodegradation in membrane bioreactor for leachate treatment. Bioresour Technol 219:53-63. https://doi.org/10.1016/j. biortech.2016.07.094

Bui TT, Giovanoulis G, Cousins AP, Magnér J, Cousins IT, de Wit CA (2016) Human exposure, hazard and risk of alternative plasticizers to phthalate esters. Sci Total Environ 541:451-467. https://doi.org/ 10.1016/j.scitotenv.2015.09.036

Carić H (2016) Challenges and prospects of valuation - cruise ship pollution case. J Clean Prod 111:487-498. https://doi.org/10.1016/j. jclepro.2015.01.033

Chour V (2001) Water resources protection today: end-of-pipe technology and cleaner production. Case study of the Czech Odra river watershed. Water Sci Technol 43(5):145-152. https://doi.org/10. 2166/wst.2001.0272

Connon RE, Geist J, Werner I (2012) Effect-based tools for monitoring and predicting the ecotoxicological effects of chemicals in the aquatic environment. Sensors 12(9):12741-12771. https://doi.org/10. 3390/s120912741

Crain DA, Eriksen M, Iguchi T, Jobling S, Laufer H, LeBlanc GA, Guillette LJ (2007) An ecological assessment of bisphenol-A: evidence from comparative biology. Reprod Toxicol 24(2):225-239. https://doi.org/10.1016/j.reprotox.2007.05.008

Cruise Baltic (2016) Cruise Baltic market review 2016; https://www. cruisebaltic.com/press/detail/13-03-2016-cruise-baltic-marketreview-2016. Accessed 08.01.2019

Cruise Baltic (2017) Cruise Baltic market review 2017; https://www. cruisebaltic.com/press/detail/2017-03-13-cruise-baltic-marketreview-2017-results-revealed. Accessed 03.01.2019

Dévier M-H, Mazellier P, Aït-Aïssa S, Budzinski H (2011) New challenges in environmental analytical chemistry: identification of toxic compounds in complex mixtures. C R Chim 14(7-8):766-779. https://doi.org/10.1016/j.crci.2011.04.006

Directive 1999/31/EC, The European Parliament and the Council of the EU (1999) Council directive 1999/31/EC of 26 April 1999 on the landfill of waste. Off J Eur Communities. https://doi.org/10.1017/ CBO9780511610851.045

Directive 1223/2009/EC, The European Parliament and the Council of the EU (2009) Regulation (EC) No 1223/2009 of the European parliament and of the council of 30 November 2009 on cosmetic products.

Directive 2455/2001/EC, The European Parliament and the Council of the EU (2001) Decision No 2455/2001/EC of the European Parliament and of the Council of 20 November 2001 establishing the list of priority substances in the field of water policy and amending Directive 2000/60/EC. In: Official journal of the European Communities http://eur-lex.europa.eu/pri/en/oj/dat/2003/ 1 285/1 28520031101en00330037.pdf. Accessed 05.01.2019

Directive 2005/84/EC, The European Parliament and the Council of the EU (2005) Directive 2005/84/EC of the European parliament and of the council of 14 December 2005 amending for the 22nd time Council Directive 76/769/EEC on the approximationofthe laws, regulations and administrative provisions of the Member States relating to restrictions on the marketing and use of certain dangerous substances and preparations (phthalates in toys and childcare articles).
Directive 2013/39/EU, The European Parliament and of the Council of 12 August 2013 amending Directives 2000/60/EC and 2008/105/EC as regards priority substances in the field of water policy

Directive 2018/850/EU, The European Parliament and the Council of the EU (2018) Directive (EU) 2018/850 of the European Parliament and of the Council of 30 May 2018 amending Directive 1999/31/EC on the landfill of waste.

Englert D, Zubrod JP, Schulz R, Bundschuh M (2013) Effects of municipal wastewater on aquatic ecosystem structure and function in the receiving stream. Sci Total Environ 454-455:401-410

Fan H-j, Shu H-Y, Yang H-S, Chen W-C (2006) Characteristics of landfill leachates in Central Taiwan. Sci Total Environ 361(1-3):25-37. https://doi.org/10.1016/j.scitotenv.2005.09.033

Foster PMD, Cattley RC, Mylchreest E (2000) Effects of di-n-butyl phthalate (DBP) on male reproductive development in the rat: implications for human risk assessment. Food Chem Toxicol 38:S97S99. https://doi.org/10.1016/S0278-6915(99)00128-3

Fudala-Ksiazek S, Pierpaoli M, Kulbat E, Luczkiewicz A (2016) A modern solid waste management strategy - the generation of new byproducts. Waste Manag 49:516-529. https://doi.org/10.1016/j. wasman.2016.01.022

Fudala-Ksiazek S, Pierpaoli M, Luczkiewicz A (2017) Fate and significance of phthalates and bisphenol $\mathrm{A}$ in liquid by-products generated during municipal solid waste mechanical-biological pre-treatment and disposal. Waste Manag 64:28-38. https://doi.org/10.1016/j. wasman.2017.03.040

Fudala-Ksiazek S, Sobaszek M, Luczkiewicz A, Pieczynska A, Ofiarska A, Fiszka-Borzyszkowska A, Sawczak M, Ficek M, Bogdanowicz R, Siedlecka EM (2018) Influence of the boron doping level on the electrochemical oxidation of raw landfill leachates: advanced pretreatment prior to the biological nitrogen removal. Chem Eng J 334: 1074-1084. https://doi.org/10.1016/j.cej.2017.09.196

Grandclement C, Seyssiecq I, Piram A, Wong-Wah-Chung P, Vanot G, Tiliacos N, Roche N, Doumenq P (2017) From the conventional biological wastewater treatment to hybrid processes, the evaluation of organic micropollutant removal: a review. Water Res 111:297317. https://doi.org/10.1016/j.watres.2017.01.005

Gray LE Jr, Ostby J, Furr J, Price M, Veeramachaneni DN, Parks L (2000) Perinatal exposure to the phthalates DEHP, BBP, and DINP, but not DEP, DMP, or DOTP, alters sexual differentiation of the male rat. Toxicol Sci 58(2):350-365

Hale RC (2003) Endocrine disruptors in wastewater and sludge treatment processes. Environ Health Perspect 111(10):125-126

Heinrich Z, Kozak T (2009) Unitary pollution charge typical of communal sewage. Gaz, Woda i Tech Sanit 12:20-22 (in polish); https:// www.gazwoda.pl . Accessed 09.01.2019

HELCOM Maritime Assessment (2010) Hazardous substances in the Baltic Sea - An integrated thematic assessment of hazardous substances in the Baltic Sea. In: Baltic Sea environment proceedings, vol 120B. Helsinki Commission, Helsinki

HELCOM Maritime Assessment (2018) Maritime activities in the Baltic Sea. Helsinki Commission, Washington D.C.

Hermabessiere LD, Paul-Pont I, Lacroix C, Jezequel R, Soudant P, Duflos $\mathrm{G}$ (2017) Occurrence and effects of plastic additives on marine environments and organisms: a review. Chemosphere. 182:781-793. https://doi.org/10.1016/j.chemosphere.2017.05.096

Judd S (2008) The status of membrane bioreactor technology. Trends Biotechnol 26(2):109-116. https://doi.org/10.1016/j.tibtech.2007. 11.005

Kalmykova Y, Björklund K, Strömvall AM, Blom L (2013) Partitioning of polycyclic aromatic hydrocarbons, alkylphenols, bisphenol A and phthalates in landfill leachates and stormwater. Water Res 47(3): 1317-1328. https://doi.org/10.1016/j.watres.2012.11.054

Karim M, Mark JL (2017) A preliminary comparative analysis of MBR and CAS wastewater treatment systems. Int J Water Wastewater Treat 3(2). https://doi.org/10.16966/2381-5299.138 
Kawai M, Purwanti IF, Nagao N, Slamet A, Hermana J, Toda T (2012) Seasonal variation in chemical properties and degradability by anaerobic digestion of landfill leachate at Benowo in Surabaya, Indonesia. J Environ Manag 110:267-275. https://doi.org/10.1016/ j.jenvman.2012.06.022

King County Wastewater Treatment Division (2007) Cruise ship wastewater management report. Department of Natural Resources and Parks, Seattle

Kovalevskiene L, Letinauskiene I, Strakšienė G (2017) Cruise tourism in the Baltic Sea region: Lithuanian case. Vadyba J Manag 31:71-75

Kulikowska D (2009) Charakterystyka oraz metody usuwaina zanieczyszczeń zanieczyszczeń organicznych z odcieków pochodzących z ustabilizowanych składowisk odpadów komunalnych. Ecol Chem Eng S 16(3):389-402

Kulikowska D, Klimiuk E (2008) The effect of landfill age on municipal leachate composition. Bioresour Technol 99(13):5981-5985. https://doi.org/10.1016/j.biortech.2007.10.015

Kurata Y, Ono Y, Ono Y (2008) Occurrence of phenols in leachates from municipal solid waste landfill sites in Japan. J Mater Cycles Waste Manage 10(2):144-152. https://doi.org/10.1007/s10163-008-0200$\mathrm{x}$

Larsson K, Lindh CH, Jönsson BAG, Giovanoulis G, Bibi M, Bottai M, Bergström A, Berglund M (2017) Phthalates, non-phthalate plasticizers and bisphenols in Swedish preschool dust in relation to children's exposure. Environ Int 102:114-124. https://doi.org/10.1016/j. envint.2017.02.006

Liu J, Zhang H, Zhang P, Wu Y, Gou X, Song Y, Tian Z, Zeng G (2017) Two-stage anoxic/oxic combined membrane bioreactor system for landfill leachate treatment: pollutant removal performances and microbial community. Bioresour Technol 243:738-746. https://doi. org/10.1016/j.biortech.2017.07.002

Logar I, Brouwer R, Maurer M, Ort Ch (2014) Cost-Benefit Analysis of the Swiss National Policy on Reducing Micropollutants in Treated Wastewater. Environ Sci Technol 48(21):12500-12508

Luo Y, Guo W, Ngo HH, Nghiem LD, Hai FI, Zhang J, Liang S, Wang $\mathrm{XC}$ (2014) A review on the occurrence of micropollutants in the aquatic environment and their fate and removal during wastewater treatment. Sci Total Environ 473-474:619-641. https://doi.org/10. 1016/j.scitotenv.2013.12.065

Mandal P, Dubey BK, Gupta AK (2017) Review on landfill leachate treatment by electrochemical oxidation: drawbacks, challenges and future scope. Waste Manag 69:250-273. https://doi.org/10.1016/j. wasman.2017.08.034

MEPC.227(64), The Marine Environment Protection Committee (2012) Guidelines on implementation of effluent standards and performance tests for sewage treatment plants. Resolution, Annex 22

Mitra S, Daltrophe NC, Gilron J (2016) A novel eductor-based MBR for the treatment of domestic wastewater. Water Res 100:65-79. https:// doi.org/10.1016/j.watres.2016.04.057

Morin N, Arp HPH, Hale SE (2015) Bisphenol A in solid waste materials, leachate water, and air particles from Norwegian waste-handling facilities: presence and partitioning behavior. Environ Sci Technol 49(13):7675-7683. https://doi.org/10.1021/acs.est.5b01307

Mróz D (2017) Port reception facilities for sewage - Port of Gdynia passenger traffic in Gdynia. Port Gdynia, Copenhagen, Denmark

Mylchreest E, Wallace DG, Cattley RC, Foster PMD (2000) Dosedependent alterations in androgen-regulated male reproductive development in rats exposed to di(n-butyl) phthalate during late gestation. Toxicol Sci 55(1):143-151. https://doi.org/10.1093/toxsci/ 55.1 .143

Nödler K, Voutsa D, Licha T (2014) Polar organic micropollutants in the coastal environment of different marine systems. Mar Pollut Bull 85(1):50-59. https://doi.org/10.1016/j.marpolbul.2014.06.024

Perić T, Komadina P, Račić N (2016) Wastewater pollution from cruise ships in the Adriatic Sea. PROMET Traff Transp 28(4):425-433. https://doi.org/10.7307/ptt.v28i4.2087
Pihlajamäki M, Tynkkynen N (2011) The challenge of bridging science and policy in the Baltic Sea eutrophication governance in Finland: the perspective of science. AMBIO 40(2):191-199. https://doi.org/ $10.1007 / \mathrm{s} 13280-010-0130-4$

Prior S (2013) Discharge of sewage and grey water from vessels in Antarctic Treaty waters. In: XXXVI Antarctic Treaty Consultative Meeting Brussels 2013. ASOC, Washington D.C., U.S., pp 1-17

Renou S, Givaudan JG, Poulain S, Dirassouyan F, Moulin P (2008) Landfill leachate treatment: review and opportunity. J Hazard Mater 150(3):468-493. https://doi.org/10.1016/j.jhazmat.2007.09. 077

Roslev P, Vorkamp K, Aarup J, Frederiksen K, Nielsen P (2007) Degradation of phthalate esters in an activated sludge wastewater treatment plant. Water Res 41:969-976. https://doi.org/10.1016/j. watres.2006.11.049

Schwarzbauer J, Heim S, Brinker S, Littke R (2002) Occurrence and alteration of organic contaminants in seepage and leakage water from a waste deposit landfill. Water Res 36(9):2275-2287

Sun C, Leiknes T, Weitzenböck J, Thorstensen B (2010a) Development of a biofilm-MBR for shipboard wastewater treatment: the effect of process configuration. Desalination. 250(2):745-750. https://doi. org/10.1016/j.desal.2008.11.034

Sun C, Leiknes T, Weitzenböck J, Thorstensen B (2010b) Salinity effect on a biofilm-MBR process for shipboard wastewater treatment. Sep Purif Technol 72(3):380-387. https://doi.org/10.1016/j.seppur. 2010.03.010

Suzuki Y, Yoshinaga J, Mizumoto Y, Serizawa S, Shiraishi H (2011) Foetal exposure to phthalate esters and anogenital distance in male newborns. Int J Androl 35(3):236-244. https://doi.org/10.1111/j. 1365-2605.2011.01190.x

Swan SH, Main KM, Liu F, Stewart SL, Kruse RL, Calafat AM, Mao CS, Redmon JB, Ternand CL, Sullivan S et al (2005) Decrease in anogenital distance among male infants with prenatal phthalate exposure. Environ Health Perspect 113(8):1056-1061. https://doi.org/ 10.1289/ehp. 8100

Swinarski M, Makinia J, Czerwionka K, Chrzanowska M (2009) Industrial wastewater as an external carbon source for optimization of nitrogen removal at the "Wschod" WWTP in Gdansk (Poland). Water Sci Technol 59(1):57-63. https://doi.org/10.2166/wst.2009. 774

Technical Ship Management: TSM (2019), https://www.tsmanagement. $\mathrm{pl} /$ en. Accessed 03.01.2019

Teuten E, Saquing J, Knappe D et al (2009) Transport and release of chemicals from plastics to the environment and to wildlife. Phil Trans Soc B 364:2027-2045. https://doi.org/10.1098/rstb.2008. 0284

Tröger R, Klöckner P, Ahrens L, Wiberg K (2018) Micropollutants in drinking water from source to tap - method development and application of a multiresidue screening method. Sci Total Environ 627: 1404-1432. https://doi.org/10.1016/j.scitotenv.2018.01.277

Urase T, Miyashita K (2003) Factors affecting the concentration of bisphenol A in leachates from solid waste disposal sites and its fate in treatment processes. J Mater Cycles Waste Manage 5(1):77-82. https://doi.org/10.1007/s101630300012

Westhof L, Köster S, Reich M (2016) Occurrence of micropollutants in the wastewater streams of cruise ships. Emerg Contaminants 2(4): 178-184. https://doi.org/10.1016/j.emcon.2016.10.001

Wilewska-Bien M, Granhag L, Jalkanen J-P, Johansson L, Andersson K (2018) Phosphorus flows on ships: case study from the Baltic Sea. Proc Inst Mech Eng M. https://doi.org/10.1177/1475090218761761

Wiszniowski J, Robert D, Surmacz-Gorska J, Miksch K, Weber JV (2006) Landfill leachate treatment methods: a review. Environ Chem Lett 4(1):51-61. https://doi.org/10.1007/s10311-005-0016-z

Wojciechowska E (2017) Potential and limits of landfill leachate treatment in a multi-stage subsurface flow constructed wetland - 
evaluation of organics and nitrogen removal. Bioresour Technol 236:146-154. https://doi.org/10.1016/j.biortech.2017.03.185

Wowkonowicz P, Kijeńska M (2017) Phthalate release in leachate from municipal landfills of Central Poland. PLoS One 12(3):e0174986. https://doi.org/10.1371/journal.pone.0174986

Yi X, Tran NH, Yin T, He Y, Gin KY-H (2017) Removal of selected PPCPs, EDCs, and antibiotic resistance genes in landfill leachate by a full-scale constructed wetlands system. Water Res 121:46-60. https://doi.org/10.1016/j.watres.2017.05.008
Zhang C, Wang Y (2009) Removal of dissolved organic matter and phthalic acid esters from landfill leachate through a complexationflocculation process. Waste Manag 29(1):110-116. https://doi.org/ 10.1016/j.wasman.2008.02.023

Publisher's note Springer Nature remains neutral with regard to jurisdictional claims in published maps and institutional affiliations. 